\title{
LIMINAL OBSERVATION IN MULTI-DISCIPLINARY PERFORMANCE: MTV MEETS FRANZ SCHUBERT
}

\author{
Bill J. Adams
}

Nova Southeastern University, USA

The combination of exceptional poetry and masterfully crafted music react to create the art song in which one plus one is three. The performance of the art song masterpiece "Erlkönig" is more than the sum of its parts. The words of Goethe plus the music of Schubert explode into a work of art which is simultaneously expansive and diminutive, thrilling and horrifying. In the traditional song recital format, songs are performed standing near a piano - no costumes, no special lighting, and with little more than generalized movement and facial expressions to convey the story. If one does not understand the German text or if part of the performance is recorded, how does this affect the equation? What if visual images are added which may complement or contradict the poetic story? This paper will explore performance by creating, blurring, and/or destroying relationships within song/s and throughout the audience by manipulating visual image, text, and live performance. Through this process new paradigms might be established building audiences for song recitals, creating fodder for filmmakers, inspiring the composition of new works, and providing educational tools for performers and teachers.

Keywords: Singing, Recital, Music, Performance, Song.

\section{Introduction}

Liminal Observation in Multi-Disciplinary Performance: MTV Meets Franz Schubert is an examination of a traditional format for the presentation of solo vocal music. Music for most solo vocal presentations is chosen from the Art Song repertoire and staged in a typical recital format.

Although providing opportunities to build audiences for solo vocal recitals, creating fodder for filmmakers, inspiring the composition of new solo vocal music, and developing innovative teaching methods are worthy endeavors, the scope of this study remains specific to the presentation of solo vocal music and the question of enhanced audience understanding and engagement through the addition of visual images.

In the $20^{\text {th }}$ century, musicologists began describing a large array of solo vocal music, much of which was composed in the Romantic $19^{\text {th }}$ century, as Art Song. In the foreword to his book The Art Song, James Husst Hall limited the discussion, “...to self-contained secular compositions scored by individual composers for solo voice with lute, harpsichord, or pianoforte accompaniment," (Hall, 1953). An art song may also be defined as, "A song intended primarily to be sung in recital, typically set to a poem, and having subtly interdependent vocal and piano parts," (Dictionary.com, n.d.). During the early $19^{\text {th }}$ century, collaborations with important poets such as Johann Wolfgang von Goethe, Heinrich Heine, A.S. Pushkin, for example, and composers such as Franz Schubert, Robert Schumann, Johannes Brahms, Gabriel Fauré, and Claude Debussy created an artistic synthesis. The result, whether called lied in German, chanson or 
mélodie in French, and song in English, gave the rising middle class a popular repertoire which was performable in small settings with amateur singers and an industrialized, newly improved piano. The popular music of the $19^{\text {th }}$ century has become the art music of today as the fusion of exemplary poetry and exceptional music created a performance phenomenon. Songs of this caliber are more than poems set to music with piano accompaniment; in performance, an art song creates a multiplying effect and the audience experiences a transcendent piece of art.

Today, Art Song recitals are presented by professional singers but only in markets large enough to support and appreciate such a precious commodity. The standard Art Song repertoire, which was produced by the music and literature titans of the Romantic Era, is performed primarily by voice students at student recitals. Vocal performance majors in programs at conservatories, colleges, and universities which operate in the Euro-centric model of music education prepare hour-long recitals in a traditional presentational format. The singer stands in front of a piano with only the aid of an accompanist on a bare stage with minimal theatrical lighting and sings, usually in multiple languages, a program drawn primarily from the Art Song repertoire. In a dimly lit house, the audience is expected to read translations in a printed program while the singer leads the audience through some of the most evocative literature known to man. Beginning in the junior year, recital programs are presented yearly and programs grow in variety and musical complexity as students progress through a system which is intended to synthesize the areas of vocal technique, performance, musicology, and music theory.

Student recital programs tend to be little more than checked boxes on a list of requirements to complete the vocal performance degree. Audiences are made up of other students who are required to be in attendance to fulfill their own degree requirements. The recitalist's family may be in the audience and they are no doubt baffled by the multiplicity of languages being presented.

Could a visual element assist with audience accessibility as most of the repertoire is sung in foreign languages? If a visual element, specifically a video, is added to a vocal recital, will the performance more fully engage the audience?

New presentational paradigms have already been established by symphonies who face similar audience accessibility and engagement issues. Symphony orchestras, whose repertoire is predominantly from the same Romantic Titans who developed the Art Song, are struggling to build and sustain connections with audiences. In a cbsnews.com article, Catherine Cahill, Mann Center CEO, said, "Symphony orchestras have to take a look at what are the audience demands because if they are not serving the audiences in their community, then frankly they are not relevant," (CBS News, 2015). Performing arts organizations risk extinction if they are ignorant of their cultural milieu. Even the New York Philharmonic regularly programs concerts such as Star Wars - Film Concert Series where visual elements are integrated with the symphonic music.

The only text to remotely address the issues of audience accessibility and engagement for the solo vocal recital is The Art of Song Recital by Shirlee Emmons and Stanley Sonntag. "The book presents imaginative advice and practical techniques for producing successful recitals and kindling audience excitement," (Emmons, 2002); however, the imagination of its authors never extends to the use of video or any pictorial elements at all. Emmons and Sonntag do pose the question, "Why should a music lover take the trouble to attend a recital unless the fare competes, nominally at least, with and evening of commercial television?" (Emmons, 2002). They go on to point out that the professional recording industry presents an additional concern for the vocal recital in that audiences are unaccustomed to live performance. Performances need to sound exactly like the recording and disappointment may result if a singer strays from audience expectations.

To engage the multiplying effect of Art Song and to combat its language barrier, a process was developed to reform the traditional recital format. In the new presentational format, additional information was provided to the audience in the form of a video projected near the singer while the live performance was occurring. The first video involved images filmed on an iPhone, edited in iMovie, and applied to the performance of "Wien, du Stadt meiner Träume" by Dr. Rudolf Sieczynski. The song was performed in German with no translations provided. Although the video, which contained still and moving images, was in effect a travelogue of Vienna, something began to emerge. Closer examination of 
the lyrics, also written by Dr. Sieczynski, revealed a troubling nationalism, and, while the music is lyrical in the style of Johann Strauss, the poem belies Austrian modernism.

Fourth Verse of "Wien, du Stadt meiner Träume:"

In storm and impoverished, By enemies besieged,

Austria stands tall and unmoved.

With heroes to spare,

With flashing bright swords

In shining steel armour,

Where songs and singing

In peace resound,

A trumpet will announce.

With gentle geniality,

Sturdy, strong and bloody,

A heroic race beyond number!

And when on the field of battle,

The slovenly cowards flee

Intone softly from far off this song.

(Rudolf Sieczynski, 1913)

The discovery in this first step of the new presentational format was that the poem and music may contradict each other and that the visual image may coalesce or contradict. In this case, the video matched the music. One can perhaps imagine the anxieties of a Vienna whose occupants in 1913, the year the song was written, included Leon Trotsky, Joseph Stalin, and Adolf Hitler, but this may only be experienced in the text. Without any translations, the audience's interpretation most likely was a reflection of the beauty of Vienna and how lovely the music sounded. As mentioned later, the audience for this presentation was too small to survey so one can only surmise the responses.

The second video and song pairing involved the combination of John Williams' song, "If We Were in Love," and arbitrary footage filmed with one actor in a single location. The meaning of the poem, written by Alan and Marilyn Bergman, conveyed an unsettled longing which was mirrored in the random images of the video. Although the audience was engaged, there was no language barrier in this presentational format, so assessing the response to the video was the primary focus. Discussions at a talkback following a performance revealed that audience members constructed their own scenarios based on the pictures they were seeing and the sounds they were hearing.

Returning to the Romantic Art Song repertoire with its inherent language barrier, the subject of the third video was Gabriel Fauré and Romain Bussine's "Après un rêve." Moving images ranged from falling snow on brown-leaf laden oak trees to ice-crusted forest streams to dreamy silhouettes of a girl playing piano. The final image was of a tandem, tree-hanging swing blowing in the wind with a barren wheat field in the background. While not a literal depiction of the poem, the video captured the essence of its meaning with the poem's lost love represented impressionistically. Audiences enjoyed the performances but the story in Bussine's poem and dreamlike quality of the video images did not provide enough linear motion to assess effectively the prototype recital format. The search continued for just the right combination of story, song, and visual images.

Gabriel Fauré and Sully Prudhomme's collaboration for "Au bord de l'eau" was the subject of the fourth video and the development process was synthesized. For the purposes of this study, it was necessary to a use a poem with a relatively straightforward narrative and to display moving images that provided a literal telling of the story in the poem. Prudhomme's text is romantically expressive. 


\author{
"At the Water's Edge" \\ To sit, the two together, at the edge of a stream passing by, \\ To watch it pass; \\ Just the two together, and if a cloud floats into view, \\ To watch it float; \\ In the horizon, if a roof's chimney is smoking, \\ To watch it smoke; \\ In the distance, if a flower somewhere is giving off its scent, \\ To let it be fragrant; \\ If some fruit, tasted by the bees, \\ Grows, to taste it; \\ If some bird, in the listening forest, \\ Sings, to listen to it; \\ To hear, at the foot of the willow where the water murmurs, \\ The water murmuring; \\ To not feel, as long as this dream lasts, \\ The time passing by; \\ But not feeling any great passion \\ Besides the adoration of one another; \\ Without any care for the world's worries; \\ To ignore them all; \\ And alone, happy among all the tiring things, \\ Without getting tired; \\ To feel the love, amidst all that is passing by, \\ And to miss nothing!
}

But, the story is clear and viewers were presented with a film where they watched a couple lovingly sit beside a stream and watch it pass. As events happened in the stanzas, audiences saw actors and settings display the events on the screen until the end when they watched the lovers slowly walk away as everything, according to the poem, disappears.

Two versions of this video were created; one with only the moving images of the couple in love and one with translations added for each scene. Since the quest was to improve audience accessibility and engagement, it was decided to add translations to one version of the video. (Viewers are accustomed to reading subtitles during television programs and while watching foreign films and operas.)

This developmental process led to three possible presentational formats which would be presented for audience feedback and commentary. The three presentational formats included, 1) the traditional voice recital format with translations printed in a program and no video, 2) a simultaneous performance of the art song with the video displaying a pictorial translation, and 3) a simultaneous performance of the art song with the video displaying a pictorial translation plus printed translations within the frame of each scene in the video.

Finding the ideal performance space and an interested audience was a developmental process as well. The first presentation was part of an I.D.E.A.S. Contemporary Art Chamber of Commerce exhibition in Louisville, Kentucky. While the audience was interested, none of the digital media devices worked. A performance at the Museum of Art Fort Lauderdale was most effective and gratifying with a digital technician running the media. The entire wall behind the presentation was a massive projection screen so the live performance was integrated fully into the digitally recorded performance. Unfortunately, the audience was too small to survey. At a presentation to the College Music Society in Helsinki, Finland, there was much anticipation for feedback from music educators from all over the world. Unfortunately, the presentation was scheduled in the last time slot on the last day of the conference and attendance was abysmal. 
Presentations at Nova Southeastern University's Lifelong Learning Institute (LLI) in the College of Osteopathic Medicine proved to be the most valuable in terms of feedback. LLI is comprised of adults who seek to continue their education after retirement. These audiences were uninhibited with their responses and their feedback was invaluable. In May of 2013, the three presentational formats were presented at the LLI using Fauré's "Au bord de l'eau" as the subject of the lecture-demonstration. The following questions were asked on an anonymous survey after the performances:

\section{Survey \#1}

1. What was the story in the song?

2. What was the impact of the performance?

3. Was it moving, relatable, likable?

4. Do you consider yourself more of a music person, theater person, or film person?

5. Which made a bigger impression, the music or the story?

6. Additional comments requested.

In May of 2014, once again using Fauré's "Au bord de l'eau" as the subject of the lecturedemonstration, the three presentational formats were presented at the LLI. The following questions were asked on an anonymous survey after the performances:

\section{Survey \#2}

1. Do you prefer the presentation without the video? Why?

2. Do you prefer the presentation with the video and no translations? Why?

3. Do you prefer the presentation with the video including translations? Why?

4. Additional comments requested.

\section{Conclusion}

Results of Survey \#1 indicated that in an audience of 37, 27\% identified themselves as music lovers, $24 \%$ identified as theater goers, $40 \%$ identified as film buffs, and $9 \%$ were undeclared. $59 \%$ of the audience felt that the music made a greater impression than the story.

Written comments included:

Just interesting - not totally engaging.

My imagination takes me on a different journey.

Likable...not particularly moving.

Likable.

Results of Survey \#2 indicated that in an audience of 32, about half preferred the presentation with no video and half preferred the presentation with the printed translation in each scene. The vote was split on liking and disliking the video with no text at all.

Written comments included:

All this was distracting from the music and words.

My imagination allows greater enjoyment and enhances the music.

Projected translation help[ful] but needs to be easier to read.

Visual adds depth.

A filmmaker would make it more artful.

More senses created more feelings. 
It was interesting to note in an audience of people aged 60 and older that the preference was for a solo vocal presentation minus the visual element. The audience did not find the presentation more engaging with the video. However, it was surprising to note that in this same audience there was a lack of aversion to the addition of the visual element to the solo vocal performance with printed translations on scenes throughout. The video did assist with audience accessibility.

What began as a liminal study, where an audience was observed and questioned in their response to various alternations of performance formats, evolved into a fresh look at the vocal recital and its possibilities, and through this examination, new scenarios are imagined for liminal observation. How would the post-MTV audience respond to the presentational formats in this study?

\section{References}

1. Art Song. (n.d.). Dictionary.com Unabridged. Retrieved June 3, 2017 from Dictionary.com website http://www.dictionary.com/browse/art-song

2. Emmons, S., \& Sonntag, S. (2002). The Art of the Song Recital. Long Grove, IL: Waveland Press.

3. Hall, J. H., (1953). The Art Song. Norman, OK: University of Oklahoma Press.

4. How video games are saving symphony orchestras. (2015, November 7). CBS This Morning. Retrieved from http://www.cbsnews.com/news/how-video-games-are-saving-symphony-orchestras-and-filling-concert-halls/

5. National Association of Schools of Music Handbook. (2016-17). Retrieved from https://nasm.artsaccredit.org/wp-content/uploads/sites/2/2015/11/NASM_HANDBOOK_2016-17.pdf

6. New York Philharmonic Season Highlights. (2017-18). Retrieved from https://nyphil.org/concerts-tickets/explore/1718/season-highlights

7. Northern Kentucky University Department of Music Vocal and Choral Studies Student Handbook. (2012). Retrieved from http://civicengagement.nku.edu/content/dam/Music/docs/VocalHandbook.pdf

8. Nova Southeastern University Lifelong Learning Institute. (2017). Retrieved from http://osteopathic.nova.edu/lii/index.html

9. Prudhomme, S. (1875). Au bord de l'eau [At the water's edge]. Translation retrieved from http://lyricstranslate.com/en/au-bord-de-leau-waters-edge.html

10. Sieczynski, R. (1913). Wien, du Stadt meiner Träume [Vienna, city of my dreams]. Translation retrieved from http://nuspel.org/Wien.html

11. Stevens, D. (Ed.). (1970). A History of Song Revised Edition. New York, NY: W. W. Norton \& Company.

12. University of Las Vegas Vocal Handbook. (2017). Retrieved from https://www.unlv.edu/sites/default/files/page_files/1768/VocalHandbookSpring2017.pdf

13. Walker, A. (2013, April 18). 1913: When Hitler, Trotsky, Tito, Freud and Stalin all lived in the same place. BBC News Magazine. Retrieved from http://www.bbc.com/news/magazine-21859771 